\title{
LASER WELDING OF NEW GRADE OF ADVANCED HIGH STRENGTH STEEL STRENX 1100 MC
}

\begin{abstract}
The article presents results of investigations on autogenous laser welding of new grade STRENX $1100 \mathrm{MC}$ steel. The modern Disk laser was applied for of $5.0 \mathrm{~mm}$ thick butt joints welding. The influence of laser welding parameters, mainly the energy input of laser welding on the penetration shape, weld quality, structure and mechanical performance was investigated. It was found that the investigated steel has surprisingly low carbon equivalent CET just 0.328 , and also relatively high temperature of martensitic transformation $\mathrm{M}_{\mathrm{s}}$ at $430.6^{\circ} \mathrm{C}$. Despite very rapid cooling times $\mathrm{t}_{8 / 5}$ in a range from 0.6 to $1.3 \mathrm{~s}$, thus rapid solidification there was no tendency to cracking of weld metal or HAZ. Significant drop of microhardness in the HAZ resulted in a decrease of tensile strength of joints, compared to the base metal. Impact toughness of test joints was at only $50 \div 60 \%$ of the base metal.

Keywords: laser welding, disk laser, advanced high strength steel, fine-grain steel, butt joint
\end{abstract}

\section{Introduction}

Modern structural steels are widely used in the manufacture of building structures such as bridges, towers, industrial buildings such production halls, warehouse hall, and also in manufacture of vehicles, particularly heavy vehicles such as trucks, trailers, semi-trailers, rail vehicles such wagons and tramcars, and also other utility vehicles and machines as cranes, loaders, excavators, etc. [1-5]. The reason for this is the ease of shaping, forming and joining of steel blanks [6-9].

In accordance with the global trend to reduce carbon dioxide emissions, reduce energy consumption, the steel industry strives to improve strength and reliability of new grades of steels. Thanks to the higher strength of steel products it is possible to reduce structures or vehicles weight while increasing its capacity [10-13].

The current level of materials science, engineering, and production engineering allows the production of super-strength steels with the yield point up to $1300 \mathrm{MPa}$. Due to the high flexibility and a number of advantages which has a fusion welding, this technology is widely used in the manufacture of steel structures [2,14-16]. Contemporary experience shows that the production of steel with excellent functional properties is not difficult. Currently, the real challenge is the technology of welding such high strength steels [2,17-19].

Still the weakest link in the structure made of high strength steel is the welded joint. Conventional welding methods such as manual metal arc welding (MMAW), gas metal arc welding (GMAW) or submerged arc welding (SMAW) don't provide satisfactory joint properties, especially in a case of steel grades with the yield point beyond $900 \mathrm{MPa}$. Therefore, steel manufacturers are constantly looking for new solutions in the production process, the methods of forming properties and improve the weldability of modern high strength steels [1-3,20-23].

As a result of the research and development carried out by the biggest steel making companies new steel grades are introduced to the market $[1,24]$. An example is the steel grade (trade name) DOMEX 960 introduced by the SSAB company in 2012. The new grade of steel was compared and classified by the manufacturer to the thermomechanically rolled fine-grained microalloyed steels, despite the fact that the standard EN 10149-2 covers steels with the yield point up to $700 \mathrm{MPa}$, e.g. S700MC. On the other hand the steel grades of the well-known trade name WELDOX were assigned to the standard EN 10025-6 for low alloy quenched and tempered steels. However, modern steels currently manufactured greater than the standards both in terms of strength and sophisticated chemical composition [25].

However, modern grades of steel that are nowadays manufactured exceed the standards both in terms of strength and chemical composition. Additionally it is difficult to classify them in terms of the manufacturing process. An example is the latest grade of steel STRENX $1100 \mathrm{MC}$, which was introduced to the world market in the spring of 2015. According to the new philosophy of SSAB Company the new steel grade STRENX covers the early grades of steel DOMEX, WELDOX and OPTIM. This example demonstrates that this new steel grade STRENX can't be classified by just one standard, in general. The new grade of steel STRENX $1100 \mathrm{MC}$ was originally produced as DOMEX

\footnotetext{
* WSB UNIVERSITY OF CHORZÓW, FACULTY OF WSB UNIVERSITY IN POZNAŃ, DEPARTMENT OF MANAGEMENT ENGINEERING, 29 SPORTOWA STR., 42-506 CHORZÓW, POLAND ** BIALYSTOK UNIVERSITY OF TECHNOLOGY, MECHANICAL FACULTY, 45C WIEJSKA STR, 16-351 BIAEYSTOK, POLAND

*** SILESIAN UNIVERSITY OF TECHNOLOGY, FACULTY OF MECHANICAL ENGINEERING, WELDING DEPARTMENT, 18A KONARSKIEGO STR.,41-100 GLIWICE, POLAND 
1100 and classified by the manufacturer to a thermomechanically rolled steel even though properties of the steel are at the level of the quenched and tempered steels. However, the manufacturer does not disclose the details of the manufacturing process of these steels. In general the new high strength, microalloyed and fine-grained steels are manufactured by means of a complex technology of Thermo-Mechanical Control Processing (TMCP), Fig. $1[6,26-28]$.

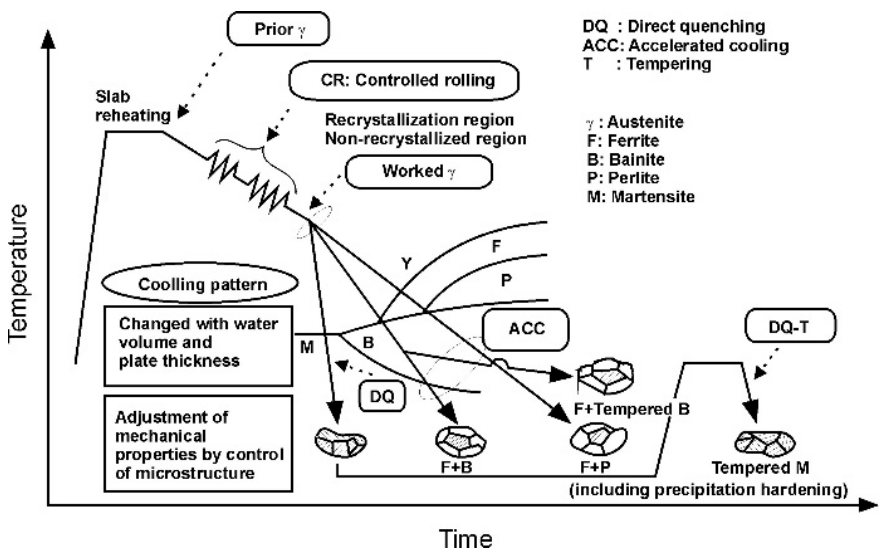

Fig. 1. Schematic illustration of thermomechanical rolling of microalloyed steels (TMCP) [6]

This complex TMCP technology provides a two phase microstructure consisting of very fine ferrite grains and bainite and/or martensite, depending on the processing conditions and also on the chemical composition, thus carbon equivalent. Modern high strength and microalloyed steels have a low carbon equivalent and are therefore considered to be well weldable with low susceptibility to cracking [2,6,29-33].

However, weldability is not just the ability to make a joint without cracks, but also the ability to provide strength and also functional properties of the joint at the level of the base material (BM) $[6,8,30,34]$.

Often the only criterion of correctness of selection of welding technology is ensuring the static tensile strength of joints at the level of the BM. Sometimes additionally the technological bending test is taken into account or the impact toughness. In practice, fatigue tests of welded joints are completely ignored [31].

Weldability is generally understood as the metallurgical weldability, which depends on the chemical composition, the structure of the welded material and the type of additional material $[2,6,24,31]$.

However, the meaning of weldability is much wider and includes the structural and technological weldability. The structural weldability depends on the type of joints, welds, thicknesses of parts to be welded, size of the structure, stiffness, etc. In turn, the technological weldability depends on the type of welding method and its characteristic, especially the power density, thus heating and subsequent cooling rate, welding speed and the associated heat input of welding, etc.

Previous studies in the field of welding of fine-grained and microalloyed steels showed that the excessive heat input during conventional arc welding has a negative impact on the properties of welded joints [1-6].

However, it should be emphasized that so far there is no information on welding of the new grade STRENX $1100 \mathrm{MC}$ steel in world literature, because the steel was introduced to the world market in the spring of 2015.

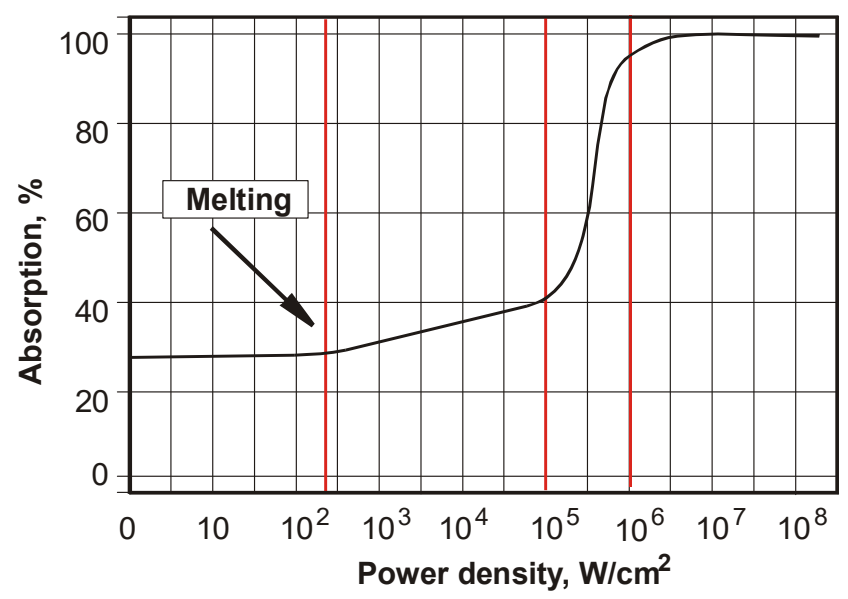

Fig. 2. Relationship between laser radiation absorption and power density of the laser beam [5]

Laser beam welding (LBW) as an advanced welding technology is of increasing importance in the world industry. The mechanisms and the conditions of laser welding are radically different from conventional arc welding processes. Moreover, the intensity of laser beam heating, mechanism of surface melting and subsequent cooling, solidification, the penetration depth, shape of the fusion zone, width/depth ratio, volume of molten metal depend on laser beam parameters (laser type), mainly on wave length, power density, Fig. 2.

Therefore, the author undertook research in the field of autogenous laser welding of new steel grade STRENX 1100 MC, recently introduced to the world industry.

\section{Material and experimental procedure}

The $5.0 \mathrm{~mm}$ thick plates of steel grade STRENX $1100 \mathrm{MC}$, currently commercially available, were chosen for laser welding tests. However the steel plates were delivered by WIELTON Company directly from Swedish steelwork as experimental plates (melt).

The new grade of steel STRENX $1100 \mathrm{MC}$ is classified by the manufacturer as thermomechanically rolled fine-grained microalloyed steel. However, the mechanical properties of this steel go far beyond the steels specified in this standard for the thermomechanically rolled steels (EN 10149-2). Additionally, details of the manufacturing process of the new grade steel are undisclosed by the manufacturer. The investigated steel with nominal chemical composition of $0.16 \% \mathrm{C}, 0.30 \% \mathrm{Si}, 1.3 \% \mathrm{Mn}$, $0.018 \% \mathrm{Al}$, and sum of $\mathrm{Nb}+\mathrm{Ti}+\mathrm{V} \max 0.18 \%$ in wt. $\%$ and balanced $\mathrm{Fe}$ has minimum yield strength $1100 \mathrm{MPa}$ and a typical 
tensile strength 1200-1460 MPa and elongation $\mathrm{A}_{5}$ min $6 \%$, for the sheet thickness $\geq 3 \mathrm{~mm}$. Specimens for the test of welding were laser cut from $5.0 \mathrm{~mm}$ thick steel plate into coupons in dimension of $100.0 \times 100.0 \mathrm{~mm}$. Surfaces and edges to be welded were sand blasted and cleaned by acetone, prior to welding tests. The trials of welding were performed by means of a modern solid state $\mathrm{Yb}$ :YAG disk laser emitted in continuous wave (cw) mode at $1.03 \mu \mathrm{m}$ wavelength with maximum output power of $3.3 \mathrm{~kW}$. The laser beam transmitted by fiberglass from the generator to the welding head was focused to a diameter of $200 \mu \mathrm{m}$. First the beadon-plate welds were produced at maximum output laser power of $3.3 \mathrm{~kW}$ and different welding speed as presented in Table 2.

TABLE 1

Technical data of the Yb:YAG TruDisk 3302 laser and the focusing optics, Fig. 3

\begin{tabular}{|c|c|}
\hline Parameter & Value \\
\hline Wave length, $\mathrm{nm}$ & 1030 \\
\hline Maximum output power, $\mathrm{W}$ & 3300 \\
\hline Laser beam divergence, $\mathrm{mm} \cdot \mathrm{mrad}$ & $<8.0$ \\
\hline Fiber core diameter, $\mu \mathrm{m}$ & 200.0 \\
\hline Collimator focal length, $\mathrm{mm}$ & 200.0 \\
\hline Focusing lens focal length, $\mathrm{mm}$ & 200.0 \\
\hline Beam spot diameter, $\mu \mathrm{m}$ & 200.0 \\
\hline Fiber length, $\mathrm{m}$ & 20.0 \\
\hline
\end{tabular}

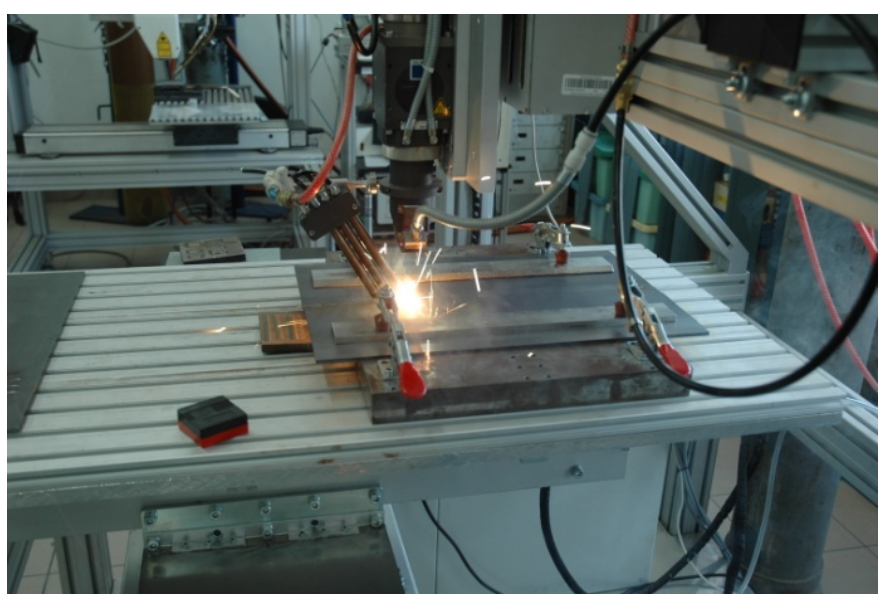

Fig. 3. A view of the autogenous laser welding of a butt joint of STRENX $1100 \mathrm{MC}$ steel plate having a thickness $5.0 \mathrm{~mm}$ and a length $500 \mathrm{~mm}$, by means of the Yb:YAG TruDisk 3302 laser (Welding Department of Silesian University in Gliwice)

The bead-on-plate welding tests were carried out to simulate the process of autogenous laser welding of butt joints and also to investigate the influence of welding parameters on the penetration depth, fusion zone (FZ) shape, and size of the heat affected zone (HAZ). Based on the bead-on-plate welding tests the optimal parameters for butt joints welding were chosen. Butt joints were one-side autogenously laser welded at maximum laser power of $3.3 \mathrm{~kW}$ and welding speed 1.5 (joint A) and $1.0 \mathrm{~m} / \mathrm{min}$ (joint $\mathrm{B}$ ) respectively. The specimens to be welded were mounted in a special clamping device to protect against distortions. The
TABLE 2

Parameters of bead-on-plate laser welding of $5.0 \mathrm{~mm}$ thick plates of STRENX 1100 MC steel, using the Disk laser TRUMPF TruDisk 3302, Fig. 3

\begin{tabular}{|c|c|c|c|c|}
\hline \hline $\begin{array}{c}\text { Bead } \\
\text { No. }\end{array}$ & $\begin{array}{c}\text { Welding } \\
\text { speed } \\
(\mathbf{m} / \mathbf{m i n})\end{array}$ & $\begin{array}{c}\text { Laser } \\
\text { power } \\
(\mathbf{W})\end{array}$ & $\begin{array}{c}\text { Energy } \\
\text { input } \\
(\mathbf{J} / \mathbf{m m})\end{array}$ & Remarks \\
\hline 1 & 2 & 3.3 & 99 & LP, UF, S \\
\hline 2 & 1 & 3.3 & 198 & S, ERR, HF, FP \\
\hline 3 & 1.5 & 3.3 & 132 & HF, ERR, SP, FP \\
\hline 4 & 0.5 & 3.3 & 396 & UF, S, FP, SP, HF, ERR \\
\hline
\end{tabular}

Other welding parameters; nominal beam spot diameter: $200.0 \mathrm{~mm}$, shielding nozzle diameter: $8.0 \mathrm{~mm}$, shielding gas: $\operatorname{Ar}(99.999 \%)$, gas feed rate on the top surface (face of weld): $15.0 \mathrm{l} / \mathrm{min}$, Quality assessment of the welds: LP - lack of penetration FP - full penetration, UF - undercut of wed face, $\mathrm{S}$ - spatter, HF - hollow face, ERR - excessive root reinforcement, $\mathrm{ER}$ - excessive face reinforcement, $\mathrm{SP}$ - single pore

laser beam interaction region, especially the weld pool was protected by argon flow via four cylindrical nozzles $8.0 \mathrm{~mm}$ in diameter each and set at an angle of $45^{\circ}$ to the joint surface. The system of shielding gas delivery and the nozzles were integrated with the laser welding head. The flow of argon was kept constant at $15 \mathrm{l} / \mathrm{min}$. Laser beam was focused on the top surface of specimens to be welded. The laser beam diameter was $200 \mu \mathrm{m}$ at the applied configuration of focusing optics. When the laser welding tests were completed, first the visual inspections (VT) were performed according to the procedure of quality control in welding. Next the metallographic and also mechanical examinations were done. Examination of the structure was carried out by means of optical microscopes (OM), Scanning Electron Microscope (SEM). Chemical composition of the base metal was determined by Glow Discharge Spectrometer (GDS). In turn, mechanical tests included the technological bending test, static tensile test and Charpy V- notch test, and also the Vickers microhardness measurements. Results of the study, measurements and analysis are given on the Figs. 4-11 and in the Tables 2-4.

\section{Results and discussion}

Results of the initial trials of bead-on-plate laser welding showed that the energy input required for full penetration of the $5.0 \mathrm{~mm}$ thick plate of STRENX $1100 \mathrm{MC}$ steel is at least $100 \mathrm{~J} / \mathrm{mm}$, at the maximum output power $3.3 \mathrm{~kW}$ of applied Disk laser TRUMPF TruDisk 3302 and at welding speed $2.0 \mathrm{~m} / \mathrm{min}$, Fig. 4a.

The width of a weld face produced at the minimum energy input of laser bead-on-plate welding is just $1.45 \mathrm{~mm}$, while the root width is from 0 to $0.25 \mathrm{~mm}$. Close inspections of the weld root during visual testing have revealed local lack of fusion (penetration), Table 2. Shape of the fusion zone (FZ) of the beadon-plate weld produced at the minimum energy input clearly indicate that the weld was produced at the keyhole welding mode, characteristic for laser beam with high power density. In this case the FZ is in columnar configuration and the depth/width 
a)

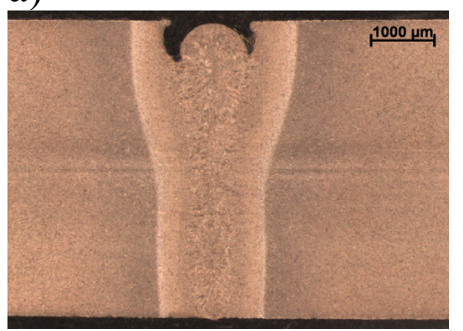

c)

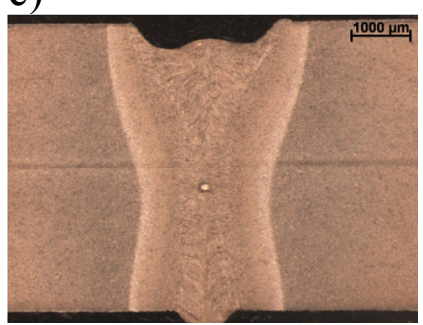

b)

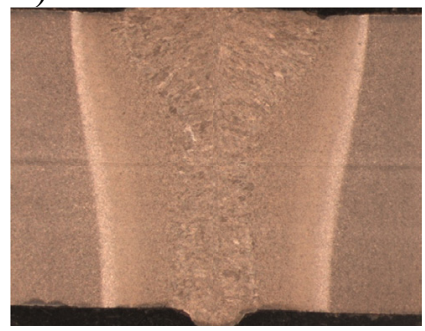

d)

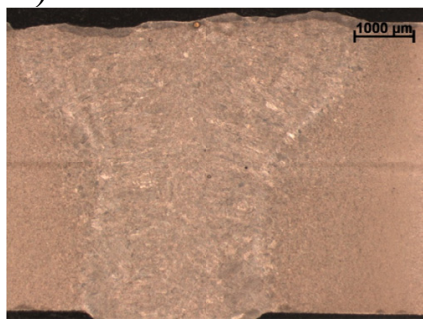

Fig. 4. Macrostructure on cross sections of the bead-on-plate welds produced on $5.0 \mathrm{~mm}$ thick plates of STRENX $1100 \mathrm{MC}$ steel by the Disk laser TRUMPF TruDisk 3302, Table 2; a) bead No. 1 (99 J/mm), b) bead No. $2(198 \mathrm{~J} / \mathrm{mm})$, c) bead No. $3(132 \mathrm{~J} / \mathrm{mm}), \mathrm{d})$ bead No. $4(396 \mathrm{~J} / \mathrm{mm})$

ratio is almost 3.5. Increasing the heat input of bead-on-plate laser welding, by lowering the welding speed at constant laser power, increases the width of a single weld and also increases the width of heat affected zone (HAZ), Fig. 4. Close observation of the macrographs of bead-on-plate welds reveled single pores in a case of the bead No. 3, localized right in the middle of the FZ, and also in the bean No. 4, localized just under the weld face, Fig. 4. Additionally undercuts of weld faces may be found in a case of bead No. 1 and 3, Fig. 4. However, it should be pointed that there are no cracks in the welds neither in heat affected zones. The width of a weld face produced at the maximum energy input of $396 \mathrm{~J} / \mathrm{mm}$ is over $6.0 \mathrm{~mm}$, which indicates an excessive welding energy input. In this case the HAZ width is over $1.5 \mathrm{~mm}$ each side, Fig. $4 \mathrm{~d}$. Thus, the optimal parameters for welding were chosen parameters No. 3 and 4, Table 2.

a)

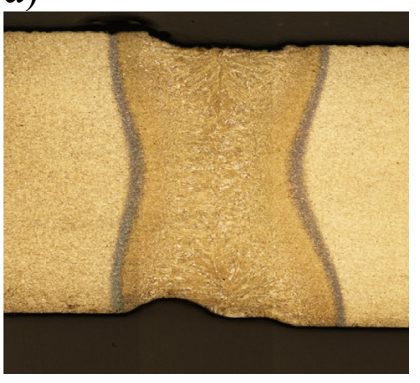

b)

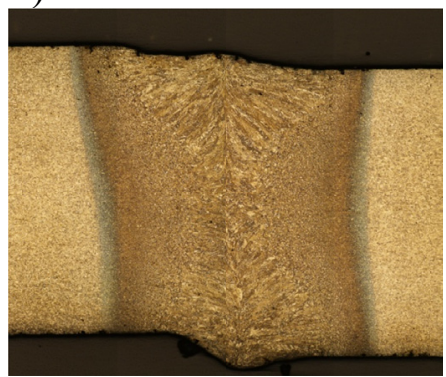

Fig. 5. Optical micrographs of the $5.0 \mathrm{~mm}$ thick butt joints of STRENX $1100 \mathrm{MC}$ steel produced by autogenous laser welding, Table 4; a) joint A (3.3 kW, $1.5 \mathrm{~m} / \mathrm{min}$, energy input $132 \mathrm{~J} / \mathrm{mm})$, b) joint $\mathrm{B}(3.3 \mathrm{~kW}, 1.0$ $\mathrm{m} / \mathrm{min}$, heat input $198 \mathrm{~J} / \mathrm{mm}$ )

The visual inspections (VT) of the test butt joints revealed a proper shape of the test joint B welded at $1.0 \mathrm{~mm} / \mathrm{min}$, thus the energy input of $198 \mathrm{~J} / \mathrm{mm}$. In this case the surfaces of face and root are flat and even with proper reinforcements, Fig. 5b. While in the case of test joint A, welded at lower energy input of $132 \mathrm{~J} / \mathrm{mm}$, undercuts of root and also slight collapse of the weld face was found. Macrographs of these test joints showed a proper shape of the FZ, Fig. 5. However, in contrast to the columnar shape of the bead-on-plate welds, the shape of the test butt joints is in X configurations, so-called hourglass configurations. Such a shape is also characteristic for keyhole mode of laser welding. The depth/width ratio for the test joint $A$ is almost 1.9, while for the test joint $\mathrm{B}$ it is about 1.15. No internal imperfections were found on the macrographs of test joints. High quality of the test joints were also confirmed by microscopic observations and mechanical tests.

The technological bending test revealed limited plasticity of the test butt joints of STRENX $1100 \mathrm{MC}$ steel, Fig. 6. The maximum angle of bending was $85 \div 90^{\circ}$ for both joints. During the static tensile tests all the samples were broken in the weld metal, Fig. 7, Table 3.

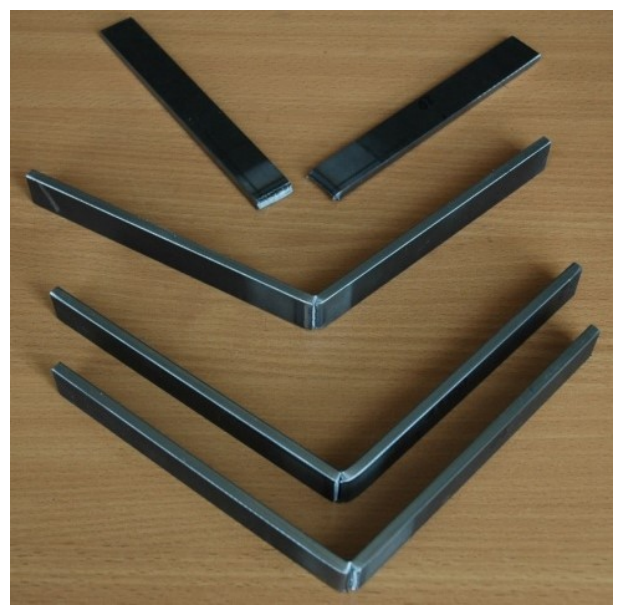

Fig. 6. A view of the samples after technological bend test of $5.0 \mathrm{~mm}$ thick butt joints of STRENX $1100 \mathrm{MC}$ steel autogenous laser welded by the Disk laser, evaluated according to the PN-EN 895 standard (from the bottom 2 test samples of joint $\mathrm{B}$ and A respectively)

TABLE 3

Results of the tensile strength test of base metal and $5.0 \mathrm{~mm}$ thick butt joints of STRENX $1100 \mathrm{MC}$ steel laser welded by the disk laser, evaluated according to the PN-EN 895 standard, Fig. 7

\begin{tabular}{|c|c|c|c|}
\hline \hline $\begin{array}{c}\text { Sample } \\
\text { type }\end{array}$ & Sample No. & $\begin{array}{c}\text { Tensile strength } \\
\text { Rm, MPa }\end{array}$ & Place of break \\
\hline \multirow{2}{*}{$\mathrm{A}$} & $\mathrm{A} 1$ & 1295 & $\mathrm{WM}$ \\
\cline { 2 - 4 } & $\mathrm{A} 2$ & 1250 & $\mathrm{WM}$ \\
\hline \multirow{2}{*}{$\mathrm{B}$} & $\mathrm{B} 1$ & 1240 & $\mathrm{WM}$ \\
\cline { 2 - 4 } & $\mathrm{B} 2$ & 1192 & $\mathrm{WM}$ \\
\hline \multirow{2}{*}{$\mathrm{BM}$} & $\mathrm{BM} 1$ & 1340 & - \\
\cline { 2 - 4 } & $\mathrm{BM} 2$ & 1324 & - \\
\hline
\end{tabular}

Remarks; WM - weld metal, BM - base metal

Such a result should be considered negative, but the tensile strength was only slightly lower than the BM, at the level 1192-1295 MPa, compared to the tensile strength of the base metal at 1324-1340 MPa, Table 3. 
a)

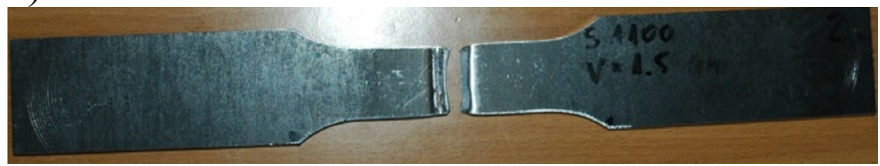

b)

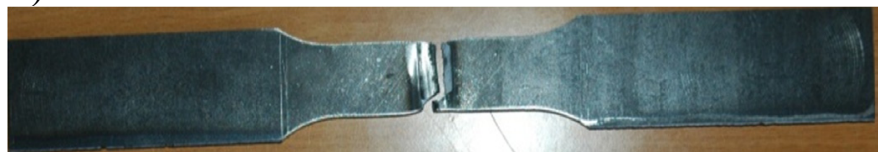

Fig. 7. A view of the broken samples from the tensile tests of butt joint A welded at $3.3 \mathrm{~kW}$ and welding speed of $1.5 \mathrm{~m} / \mathrm{min}$ (energy input of $132 \mathrm{~J} / \mathrm{mm}$ ) (a) and the joint B welded at $3.3 \mathrm{~kW}$ and welding speed of $1.0 \mathrm{~m} / \mathrm{min}$ (energy input of $198 \mathrm{~J} / \mathrm{mm}$ ) (b)

Charpy V- notch test, performed at room temperature, revealed that the impact toughness of laser welded test butt joints is clearly lower compared to the impact toughness base metal of STRENX 1100 MC steel.

TABLE 4

Results of the impact toughness test of $5.0 \mathrm{~mm}$ thick butt joints of STRENX 1100 MC steel laser welded by Disk laser, evaluated according to the PN-EN 10045-1 standard, Fig. 8

\begin{tabular}{|c|c|c|c|}
\hline \multirow{2}{*}{\multicolumn{2}{|c|}{ Joint type/sample No. }} & \multicolumn{2}{|c|}{ Impact toughness, $\mathrm{J} / \mathrm{cm}^{2}$} \\
\hline & & Single value & Mean value \\
\hline \multirow{3}{*}{ A } & $1 \mathrm{~A}$ & 57.9 & \multirow{3}{*}{70.6} \\
\hline & $2 \mathrm{~A}$ & 78 & \\
\hline & $3 \mathrm{~A}$ & 76 & \\
\hline \multirow{3}{*}{ B } & $1 \mathrm{~B}$ & 68 & \multirow{3}{*}{86.13} \\
\hline & $2 \mathrm{~B}$ & 108.4 & \\
\hline & $3 \mathrm{~B}$ & 82 & \\
\hline \multirow{3}{*}{$\mathrm{BM}$} & $1 \mathrm{BM}$ & 142 & \multirow{3}{*}{142} \\
\hline & $2 \mathrm{BM}$ & 141 & \\
\hline & $3 \mathrm{BM}$ & 143 & \\
\hline
\end{tabular}

The results of the impact toughness tests determined for the base metal of STRENX $1100 \mathrm{MC}$ steel were very consistent, and ranged from 141 to $143 \mathrm{~J} / \mathrm{cm}^{2}$. The impact toughness of the test joint welded at energy input $132 \mathrm{~J} / \mathrm{mm}$ was in a range from 57.9 to $78 \mathrm{~J} / \mathrm{cm}^{2}$, at the average value of just $70.6 \mathrm{~J} / \mathrm{cm}^{2}$, Table 4 . So the impact toughness of this joint is as low as $49.7 \%$ toughness of the base metal of STRENX $1100 \mathrm{MC}$ steel. In turn, the impact toughness of the second test joint B welded at higher energy input of $198 \mathrm{~J} / \mathrm{mm}$ is $86.13 \mathrm{~J} / \mathrm{cm}^{2}$, so approx. $60.6 \%$ toughness of the base metal. Fracture surfaces of test joints are presented in Figure 8. As can be seen the fracture surfaces indicate rather ductile dimple fracture mode in both cases. So, although the impact toughness of test joints is clearly lower compared to the base metal, the fracture mode is ductile. The results suggest that the impact toughness of the test butt joints may depend on the energy input of autogenous laser welding in the investigated range of parameters, thus thermal conditions, cooling rates and thus structure of the weld metal and HAZ.

The cooling times $t_{8 / 5}$ between the temperature range 800 to $500^{\circ} \mathrm{C}$ were calculated for different energy inputs of laser a)

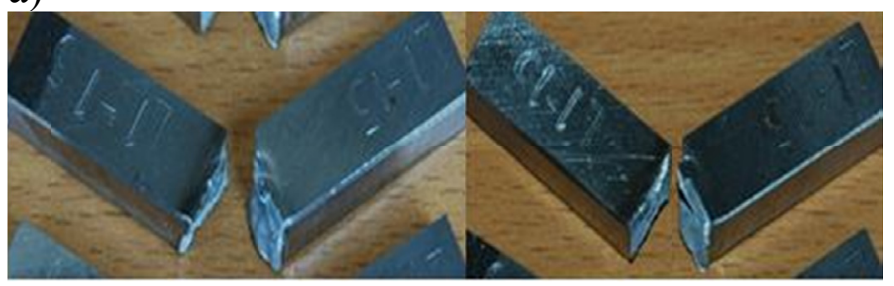

b)

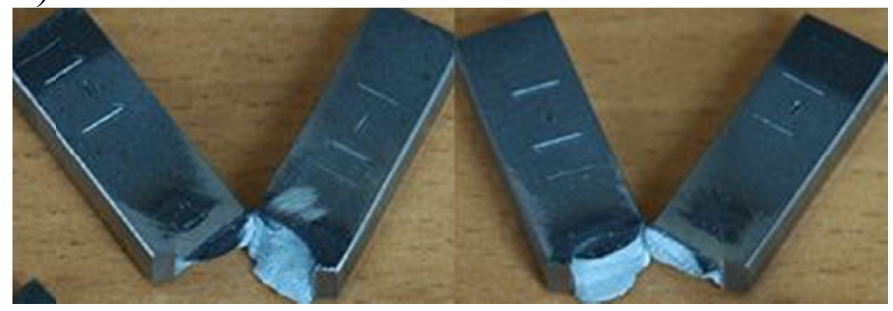

Fig. 8. A view of broken impact samples of the test joint A (a) and test joint B (b), Table 4

welding by means of the equation developed and described in details in Reference 1 . For the energy input $198 \mathrm{~J} / \mathrm{mm}$ of butt laser welding of the $5.0 \mathrm{~mm}$ thick steel plates the calculated cooling time $t_{8 / 5}$ was $1.299 \mathrm{~s}$. While the cooling time in a case of lower energy input $132 \mathrm{~J} / \mathrm{mm}$ was just $0.577 \mathrm{~s}$. For comparison, in both cases, cooling times $\mathrm{t}_{8 / 5}$ are significantly lower than recommended for the quenched and tempered steel grades, in the range 5 to $15 \mathrm{~s}$. However, despite such short cooling times there was no tendency to cold cracking (hydrogen cracking) of the test joints, Fig. 5.

The microhardness profiles determined on the cross sections of welded butt joints have shown a significant drop of microhardness in the heat affected zone adjacent to the fusion zone, Fig. 9. Microhardness of base metal is in a range from 400 to $450 \mathrm{HV} 0.2$, while the minimum value of microhardness in the $\mathrm{HAZ}$ is $300 \mathrm{HV} 0.2$ or even below $300 \mathrm{HV} 0.2$, as can be seen in Fig. 9. Microhardness in the fusion zone, i.e. in the weld metal, is fairly stable at the level of 400 to $450 \mathrm{HV} 0.2$, Fig. 9. So the reason for the relatively low tensile strength of the test joints is a decrease in microhardness in the HAZ adjacent directly to the FZ. The microhardness decrease in the HAZ is gradual and the value of the microhardness in the individual regions (subregions) of HAZ depends on the microstructure, and this in turn on the on the chemical composition and tendency to hardening.

The GDS analysis showed that the investigated STRENX $1100 \mathrm{MC}$ steel contains $0.139 \% \mathrm{C}, 0.31 \% \mathrm{Si}, 1.40 \% \mathrm{Mn}, 0.7 \% \mathrm{Cr}$, $0.3 \% \mathrm{Ni}, 0.06 \% \mathrm{Mo}, 0.039 \% \mathrm{Al}, 0.01 \%$ each $\mathrm{Ti}$ and $\mathrm{Cu}, 0.006 \% \mathrm{~V}$, and $0.001 \% \mathrm{Nb}$. Based on the determined composition, the martensitic transformation temperature was calculated according to the following equation: $\mathrm{M}_{\mathrm{s}}\left({ }^{\circ} \mathrm{C}\right)=561-474(\% \mathrm{C})-33(\%$ $\mathrm{Mn})-17(\% \mathrm{Ni})-17(\% \mathrm{Cr})-21(\% \mathrm{Mo})$. The calculated $\mathrm{M}_{\mathrm{s}}$ temperature is equal to $430.6^{\circ} \mathrm{C}$, so very close to the $\mathrm{M}_{\mathrm{s}}$ temperature determined in previous investigations for the DOMEX 960 steel $\left(429.1^{\circ} \mathrm{C}\right)$ [2]. Additionally the carbon equivalent CET was determined according to the following equation: $\mathrm{CET}=\mathrm{C}+(\mathrm{Mn}$ $+\mathrm{Mo}) / 10+(\mathrm{Cr}+\mathrm{Cu}) / 20+\mathrm{Ni} / 40$. The value of the calculate $\mathrm{CET}$ 
a)

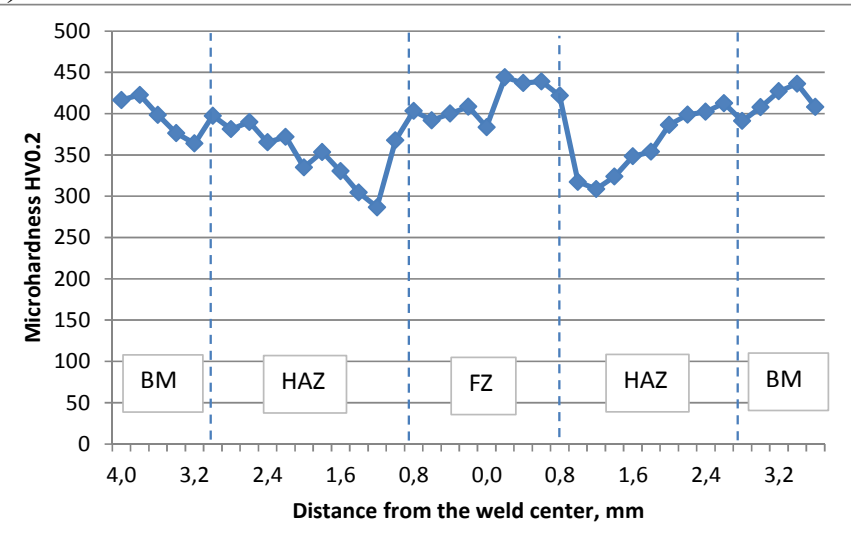

b)

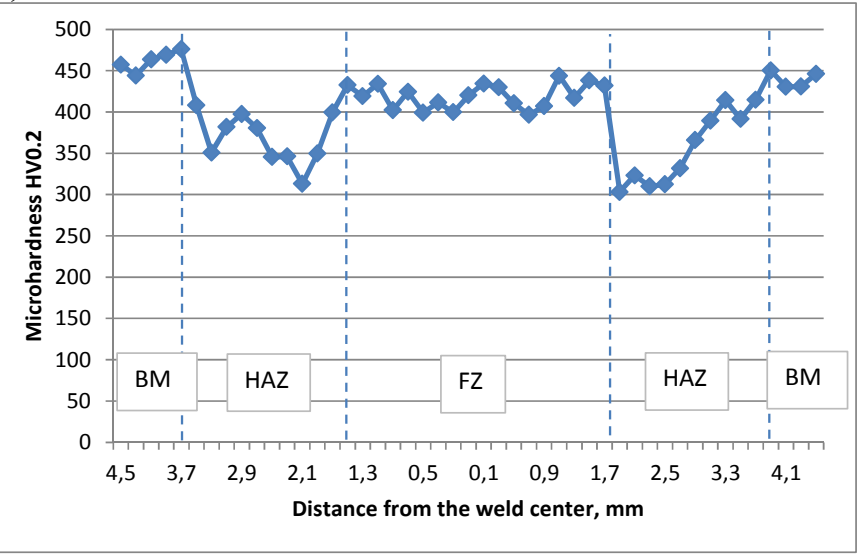

Fig. 9. Microhardness distribution on the cross-section of $5.0 \mathrm{~mm}$ thick butt joints of STRENX $1100 \mathrm{MC}$ steel welded by the Disk laser; a) joint A (energy input $132 \mathrm{~J} / \mathrm{mm}$ ), b) joint B (energy input $198 \mathrm{~J} / \mathrm{mm}$ )

is just 0.328 , so even below the carbon equivalent determined previously for the DOMEX 960 (CET 0.343) [2]. Both the high $\mathrm{M}_{\mathrm{s}}$ temperature and surprisingly low carbon equivalent indicate that the hardenability of the investigated steel is not very high. Structure of the base metal of STRENX 1100MC steel is shown in Figure 10.

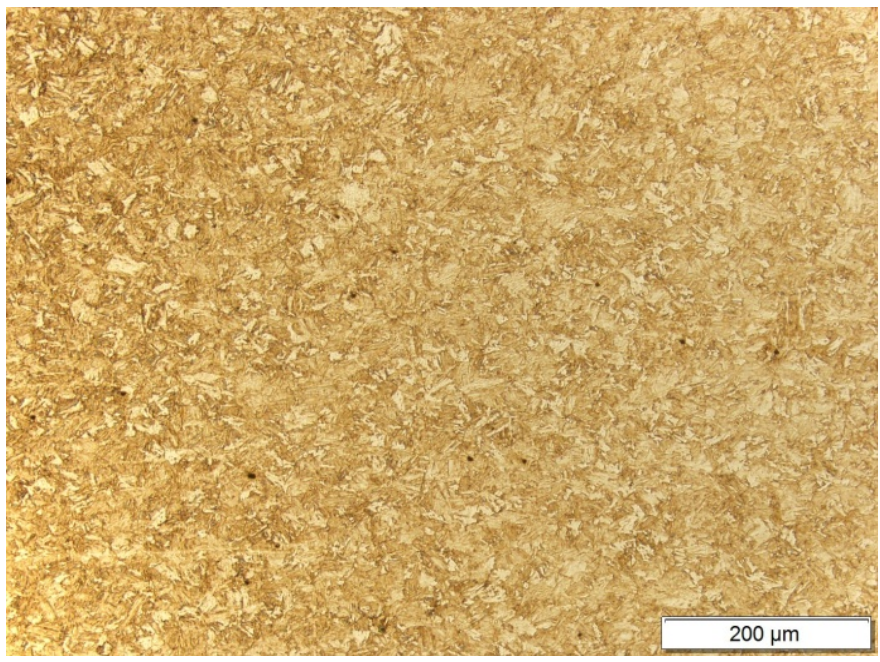

Fig. 10. Microstructure of the base metal of $5.0 \mathrm{~mm}$ thick plate of STRENX $1100 \mathrm{MC}$ steel
As can be seen the investigated STRENX $1100 \mathrm{MC}$ steel has a fine-grained bainitic-martensitic structure with a significant proportion of acicular ferrite and also traces of retained austenite, Fig. 10. Additionally precipitations of small carbides with high dispersion can be identified in the structure. The structure of weld metal of test butt joints produced at energy input of $132 \mathrm{~J} / \mathrm{mm}$ and $198 \mathrm{~J} / \mathrm{mm}$ respectively is presented in Figure 11 . a)

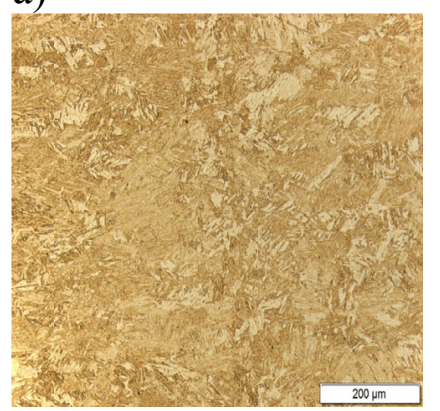

b)

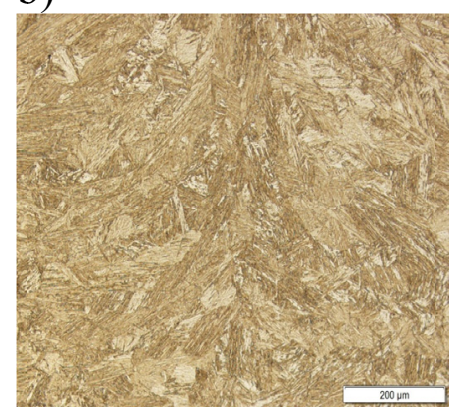

Fig. 11. Microstructure of the test butt joints; a) joint A (energy input $132 \mathrm{~J} / \mathrm{mm}$ ), b) joint B (energy input $198 \mathrm{~J} / \mathrm{mm}$ )

The structure and morphology of phase constituents in the weld metal depends on the energy input. Structure of weld metal consists mainly of bainite, fine martensitic islands, and also ferrite, mainly polygonal $\left(\alpha_{\mathrm{pf}}\right)$ and allotriomorphic ferrite $\left(\alpha_{\mathrm{af}}\right)$, Fig. 11.

\section{Conclusions}

In this study, autogenous laser welding of butt joints of new grade STRENX 1100 MC steel, which was introduced to the world market in the spring of 2015 , was investigated. It was found that laser welding of $5.0 \mathrm{~mm}$ thick butt joints by the Yb:YAG Disk laser was conducted at keyhole mode and provides high quality of joints. The investigated steel has a small amount of alloying elements (microalloyed steel), and also surprisingly low carbon equivalent CET just 0.328 , and also relatively high temperature of martensitic transformation $\mathrm{M}_{\mathrm{s}}$ about $430.6^{\circ} \mathrm{C}$. Despite the low carbon equivalent the base metal has a finegrained bainitic-martensitic structure with microhardness about 400-450 HV0.2. Under the keyhole laser welding conditions of $5.0 \mathrm{~mm}$ thick butt joints the cooling times $\mathrm{t}_{8 / 5}$ were found to be very short from $0.6 \mathrm{~s}$ for the energy input of $132 \mathrm{~J} / \mathrm{mm}$ and $1.3 \mathrm{~s}$ for the higher energy input of $198 \mathrm{~J} / \mathrm{mm}$. Despite very rapid solidification of weld metal and rapid cooling, there was no tendency to cracking of weld metal or HAZ. Significant drop in microhardness was observed in the HAZ adjacent to the fusion zone. That caused cracking of test joints in HAZ during the static tensile tests. Impact toughness of test joints was $50 \div 60 \%$ of the base metal of STRENX $1100 \mathrm{MC}$ steel. Explanation of such significant decrease in impact toughness of test joints needs further study in this field. 


\section{Acknowledgements}

Special thanks to Rafał Lis from the WIELTON Company for providing the new experimental grade of steel.

\section{REFERENCES}

[1] A. Lisiecki, Arch. Metall. Mater. 59 (4), 1625 (2014), doi:10.2478/ amm-2014-0276.

[2] A. Kurc-Lisiecka, W. Ozgowicz, E. Kalinowska-Ozgowicz et al., Materiali in Tehnologije 50 (6), 837 (2016).

[3] A. Lisiecki, Proceedings of SPIE, Laser Technology 2012: Application of Lasers, 8703 (2013), doi:10.1117/12.2013431.

[4] A. Lisiecki, Proceedings of SPIE, Laser Technology 2012: Applications of Lasers, 8703 (2013), doi:10.1117/12.2013429.

[5] A. Klimpel, L.A. Dobrzanski, D. Janicki, A. Lisiecki, J. Mater. Process. Technol. 164, 1056 (2005).

[6] A. Kurc-Lisiecka, Materiali in Tehnologije 51 (4), 643 (2017), doi:10.17222/mit.2016.234.

[7] A. Grajcar, M. Rozanski et al., Arch. Metall. Mater. 59 (3), 1163 (2014), doi:10.1155/2014/658947.

[8] J. Górka, Materiali in Tehnologije 50 (4), 617 (2016).

[9] D. Janicki, Arch. Metall. Mater. 59 (4), 1641 (2014), doi:10.2478/ amm-2014-0279.

[10] A. Kurc-Lisiecka, et al., Sol. St. Phenomena 203-204, 105 (2013), doi:10.4028/www.scientific.net/SSP.203-204.105.

[11] S. Topolska, Mater. Sci. Eng. 145, 022037(2016), doi:10.1088/1757$-899 \mathrm{X} / 145 / 2 / 022037$

[12] A. Czuprynski, J. Gorka, M. Adamiak, Metalurgija 55 (2), 173 (2016).

[13] M. Bonek, Arch. Metall. Mater. 59 (4), 1647 (2014), doi:10.2478/ amm-2014-0280.

[14] G. Moskal, A. Grabowski, A. Lisiecki, Sol. St. Phenomena 226, 121 (2015). doi:10.4028/www.scientific.net/SSP.226.121.

[15] J. Bodzenta, A. Kaźmierczak, T. Kruczek, Journal de Physique IV 129, 20 (2005)
[16] R. Burdzik, Ł. Konieczny, J. of Vibroengineering 15 (4), 1680 (2013).

[17] R. Burdzik, Ł. Konieczny, Solid State Phenomena 210, 20 (2014).

[18] R. Burdzik, J. of Vibroengineering 15 (4), 2114 (2013).

[19] Ł. Konieczny, R. Burdzik, B. Łazarz, Journal of Vibroengineering 15 (4), 2042 (2013).

[20] B. Oleksiak, G. Siwiec, A. Blacha-Grzechnik, J. Wieczorek, Metalurgija 53 (4), 605 (2014).

[21] R. Burdzik, T. Węgrzyn, Ł. Konieczny, A. Lisiecki, Arch. Metall. Mater. 59 (4), 1275 (2014), doi:10.2478/amm-2014-0218.

[22] R. Burdzik, Ł. Konieczny, Z. Stanik, P. Folęga, A. Smalcerz, Arch. Metall. Mater. 59 (3), 957 (2014).

[23] B. Szczucka-Lasota, B. Formanek, A. Hernas, K. K. Szymański, J. Mater. Process. Technol. 164-165, 935 (2005).

[24] B. Formanek, K. Szymański, B. Szczucka-Lasota, J. Mater. Process. Technol. 164-165, 850 (2005).

[25] G. Golański, P. Gawień, J. Słania, Arch. Metall. Mater. 57 (2), 1067 (2012).

[26] T. Węgrzyn, J. Piwnik, B. Łazarz, W. Tarasiuk, MECHANIKA, 21 (5), 419 (2015).

[27] T. Węgrzyn, J. Mirosławski, A. Silva, D. Pinto, M. Miros, Mat. Sci. Forum 6, 585 (2010).

[28] T. Węgrzyn, J. Piwnik et al., Arch. Metall. Mater. 57 (3), 679 (2012).

[29] T. Węgrzyn, J. Piwnik, D. Hadryś, Arch. Metall. Mater. 58 (4), 1067 (2013).

[30] G. Golański, A. Zieliński, J. Słania, J. Jasak, Arch. Metall. Mater. 59 (4), 1357 (2014).

[31] L.A. Dobrzanski, M. Bonek, A. Klimpel, A. Lisiecki, Advanced Materials Processing II, Book Series: Materials Science Forum 437-4, 69 (2003).

[32] A. Lisiecki, A. Kurc-Lisiecka, Materiali in Tehnologije 51 (1), 29 (2017), doi:10.17222/mit.2015.160.

[33] D. Janicki, Proceedings of SPIE, Laser Technology 2012: Applications of Lasers, 8703 (2013) 87030Q, doi: 10.1117/12.2013428.

[34] M. Zuk, J. Gorka, A. Czuprynski et al., Metalurgija 55 (4), 613 (2016). 